\title{
DISCUSSIONS ON THE RESEARCH PERSPECTIVES AND THE CHILDREN'S AGENCY IN SOCIOLOGY OF CHILDHOOD WITH RELATION TO CHILD ACTORS
}

Ayșe YILMAZ ${ }^{1}$

\begin{abstract}
The aim of this article is to put under discussion the major concern of the childhood studies which is the consideration of children as social actors. This theoretical examination explores the ways in which children are treated as social actors in diverse researches carried out from different perspectives. Furthermore it investigates the concept of agency, the fundamental concept to the sociology of childhood, emphasizing how it has become widely contested although it arises from the consideration of "children as actors" on which there is general consensus. Therefore this article highlights how the same assumption on children appears to be treated in various ways in relation to different research perspectives and the different uses of children's agency.
\end{abstract}

Keywords: Sociology of Childhood, Childhood Studies, Children's Agency, Children as Social Actors

${ }^{1}$ Arş. Gör., Bahçeşehir Üniversitesi İktisadi, İdari ve Sosyal Bilimler Fakültesi Sosyoloji Bölümü

$\mathrm{SAD} / \mathrm{JSR}$

Cilt / Volume 24 Sayı / Number 2 


\section{COCUKLUK SOSYOLOJISINDE ARASTIRMA PERSPEKTIFLERİ VE ÇOCUKLARIN FAİLLİĞİ ÜZERİNE ÇOCUK AKTÖRLERE İLİŞKIN TARTIŞMALAR}

\section{ÖZ}

$\mathrm{Bu}$ makalenin amacı, çocukluk araştırmalarının temel meselesi olan çocukların aktör olarak kabul edilmesini tartışmaya açmaktır. Bu teorik inceleme, farklı bakış açılarından yürütülen çeşitli araştırmalarda çocukların sosyal aktörler olarak ele alınmasının yollarını araştırmaktadır. Ayrıca çocukluk araştırmalarının temel kavramı olan failliğin, üzerinde genel bir fikir birliğinin bulunduğu "toplumsal aktör olarak çocuklar" bakış açısından kaynaklanmasına rağmen, nasıl geniş çapta tartışıldığını incelemektedir. Bu nedenle bu makale, çocukluk sosyolojisinin çocuklara ilişkin temel varsayımının, farklı araştırma perspektifleri ve çocukların failliği kavramının farklı kullanımları üzerinden nasıl ele alındığını vurgulamaktadır.

Anahtar Kelimeler: Çocukluk Sosyolojisi, Çocukluk Çalışmaları, Çocukların Failliği, Toplumsal Aktör Olarak Çocuklar 


\section{INTRODUCTION}

According to statistics of UNICEF (2019), it is known that children make up thirty percent of the total population worldwide. As members of society who constitute a third of the population, children cannot be excluded from the sociological gaze. Like all other members of society they are influenced by social, economic, political, historical factors and they contribute to them in different ways. However, children and childhood did not become sociological concerns until the turn of $20^{\text {th }}$ century, but rather they have always been research objects for pediatrics, medicine, psychology (Turmel, 2006). Their principal interest was the development of the child in mathematical terms, they measured and reduced children to simple objects of calculations. Their view of children, which was based mainly on quantitative measures, tended to make children a universal entity. Contrary to those approaches which consider the child in an idealized form standardized by the measures, arises the idea of the socially situated child towards the end of 20th century. This new way of thinking about children considers children and childhood as historically situated, social and cultural creations rather than simple natural realities (Firıncı Orman, 2018).

The emerging sociology of childhood draws the attention to the children as social actors. In this research domain, children's capacities to act and to contribute to their own social worlds are questioned. This new field of sociology changes the focal of the issues regarding children. As Christine Détrez and Clémence Peronnet point out (2020), "Childhood should no longer be thought of as a state of latency, incubation or reduced model of adulthood." The ways of inquiring children are reversed so that they would become the points of reference of their own social worlds. In sociology of childhood, starting from this assumption, we underline that children have increasingly become objects and subjects of social science research. We start researching children in their own right (Prout, 2005).

According to Régine Sirota (2006a, p. 14), emergence of the sociology of childhood is concomitant with the decline of great social stories where the symbolic interactionism and interpretative theories are 
rediscovered, a strong deinstitutionalization is highlighted, theories of individualism are gained importance, and there is a general return to the actor in sociology. As underlined, the decline of the great narratives draws our attention to a rather microsociological level and we are increasingly interested in socially and historically situated individuals. In a similar way, William Corsaro (1997, p. 6) considers the importance of the rise of the theories from the constructivist and interpretative perspectives in the new conceptualization of childhood. These perspectives allow us to examine genesis of the facts as social constructions rather than biological givens or obvious facts. "What this means is that childhood and all social objects [...] are seen as being interpreted, debated, and defined in processes of social action. In short, they are viewed as social products or constructions." With such a perspective, a value is attributed to any social object to be considered as an object of research. We no longer focus solely on the macrosociological level, but we begin to be interested in the singularities of individuals at the microsociological level. This return to the microsociological level is recognized in various researches by returning to individual actors.

This is reflected in childhood studies as a return to the children as social actors. The return to the actor does not mean the neglect of the macrosociological level. On the contrary, it facilitates positioning the social actors in larger structures establishing links between the various levels of the social. Furthermore it prevents the disappearance of singular individuals under the weight of social structures. The emergence of the sociology of childhood is described in such a scientific environment. The idea of a "general return to the actor" put into question children and their status in society. Especially after the 1980s, we see an abundance of work on childhood whose three major benchmarks are to be found in the works of Chris Jenks (1982), Wendy Stainton-Rogers, Denise Hevey and Elizabeth Ash $\quad$ (1989), and Allison James and Alan Prout (1997).

When it comes to the context of Turkey, even though the sociology of childhood has long been neglected as an academic field in Turkey (Onur, 2007), a few theoretical articles have been published recently 
focusing on the sociological concerns on children and childhood (Akbaş \& Akbaş, 2019; Aydoğmuş Ördem, 2020; Iş1k, 2019; Karabıyık, 2019), the reasons of late development of sociology of childhood in Turkey (Firıncı Orman, 2018), the neglection of children in sociology (Demir Gürdal, 2013), children's rights from a sociological point of view (Güçlü, 2016). As for this article, it contributes primarily to the sociology of childhood as it is attempted to be institutionalized in Turkey. Its major contribution resides in the fact that it focuses on the place of children as social actors in this field of sociology and questions the concept of children's agency in relation to sociology of childhood which has not been discussed earlier in the publications which have just been mentioned.

The importance of the sociology of childhood have its source from the consideration that children are social actors. Even though this is a common consideration to the researchers of sociology of childhood, they differ in two ways: their ways of conducting research and arguing children's agency from different perspectives. The aim of this article is to open a debate for discussing children's place in sociology as social actors by introducing diverse perspectives employed by researchers and the contested concept of children's "agency" from the perspective of the sociology of childhood. To this end, I will first discuss the functionalist theories of socialization which are considered to be the transitional theorizing of childhood, because the theories of socialization pave the path to the emergent sociology of childhood with a new paradigm. Then, I will discuss the main issues of the new paradigm which is the "child as a social actor". Following that I will introduce and accentuate different studies carried out from diverse perspectives in relation to child actors. Furthermore, I will put the concept of agency under discussion underlining major debates around this concept. Terminally, I will conclude the article with a discussion of the issues in the article. 


\section{TRANSITIONAL THEORIZATION OF CHILDHOOD : FUNCTIONNALIST THEORIES OF SOCIALIZATION AND THE PLACE OF CHILDREN}

Allison James, Chris Jenks and Alan Prout state that there is an epistemological break in perspectives on children between "presociological accounts of the child and the sociological approaches" (1998, p. 23). After making this distinction, they mention a transitional theorizing about the child which is the socialization. According to them, it is by means of socialization, as it was employed by the functionalist sociological paradigm of the 1950s, this conceptual divide is bridged by ensuring the transition from the presociological child to the sociological one.

In the 1950s, the developmental psychology's view on the child nourished the sociological perspectives (Piaget, 1952, 1967; Vygotsky, 1978). Its reflections on sociology showed itself through the theories of socialization. Socialization is briefly described as the way in which people are shaped and transformed by the society (Darmon, 2010). It is especially through this perspective of socialization that the child becomes an object of sociology (Sirota, 2006b, p. 14). From this point of view children are simply considered to be adults in the making and the future members of society, therefore they become individuals to be formed in and by a given society as its members through the inculcation of societal norms (Danziger, 1970; Goslin, 1969). In this regard, biological nature is neglected in individual development, rather its social aspects are put forward. The ability to become an appropriate future adult of the society is deemed important in the social development of children. As Frederick Elkin and Gerald Handel underline with regard to the capacities of newborns, it is through socialization that they are developed, otherwise their capacities are exceedingly minimal (1972, p. 6). Thereby becoming an adult is seen possible through the process of socialization by the acquisition of societal norms and values. Children are considered important not as themselves, but as future adults in society who will maintain the established social order.

$\mathrm{SAD} / \mathrm{JSR}$

Cilt / Volume 24 Sayı / Number 2 
Thus, the children are no longer approached outside their environment, but begin to be thought of socially, historically, economically and culturally (Denzin, 1977). That is to say that children and their childhoods have started to be contextualized. Children acquire the necessary capacities for integrating into society starting from the childhood, and the institutions facilitate this process. Likewise, Talcott Parsons' theory of the social system (1951) emphasizes the role of social institutions in instilling in people the instructions for becoming adults and members of a society in accordance with the norms and values of a society. First of all the family and then the school are key institutions insofar as they contribute primarily to the socialization of children. In this sense, the place attributed to the child is that of an entity that is not yet fully social, which means that the child is subject to the influence of institutions and adults in order to become social beings.

Socialization offers a transmission that has only one direction : from society to the individual. Such a view represents the power of adults and of institutions to define children, therefore children have a position dependent on adults and they are passive in acquiring the values and norms transmitted to them by society and its institutions. Since there is a transmission path from society to the child, it is assumed that the child will find its place as an adult in society in the future. In this theorization, children are rendered passive and it is the society which is paramount, imposing and determining. The active and innovative capacities of children are underestimated, therefore this approach remains deterministic in the explanation of phenomena with regard to children and their social worlds (Corsaro, 1997).

Nevertheless the importance of the theories of socialization lays in the fact that they open up considerable possibilities for thinking about children. Even though the children were regarded as passive from this perspective, theories of socialization as a transitional theorizing bring the sociological gaze to children and childhoods by giving rise to a new paradigm for childhood studies. 


\section{NEW PARADIGM FOR CHILDHOOD STUDIES AND CHILDREN AS ACTORS}

The sociology of childhood which has developed and earned its place as a pertinent field of sociology is a varied field marked by controversies. This field of research which places children at the center of the sociological regard is not at all homogeneous. Nevertheless, for a sociology of childhood the work of James and Prout entitled Constructing and Reconstructing Childhood (1997) is of prime importance, because a new paradigm is declared in this work which forms the epistemological basis for the researches regarding children and their childhoods. Almost all the researches carried out in this field refer to this paradigm which opens up new avenues in the sociological view of children. The researchers of Childhood Studies position themselves in relation to this paradigm and question the articles introduced and developed by them. Whether the researchers position for or against this paradigm, it remains a benchmark and needs to be underlined in this article for a better understanding of children as actors.

Allison James and Alan Prout (1997) describe the twentieth century as "the century of the child", where there is a preeminence of the concerns for children in "child-centered" western societies. In such societies, towards the end of the twentieth century, the state institutions are mobilized for the well-being of the child and parallelly the academic discourse begins to address the qualities of children as subjects in their own rights. According Berry Mayall (2013), adopting a sociological perspective on children will give recognition to children as members of a society who contribute to its well-being. This idea is reinforced by the ratification of the "International Convention on the Rights of the Child" (UN General Assembly, 1989). Increasingly, questions about children become more visible and the social sciences begin to take an interest in children as objects and subjects of social research. The interest of the social sciences towards children has contributed to a change in the approaches on children as well as to a change in the practice of research with and on children.

$\mathrm{SAD} / \mathrm{JSR}$

Cilt / Volume 24 Sayı / Number 2 
As a precursor in this field of study, Charlotte Hardman (2001 (1973), p. 502) states that children were considered as a "silent, unperceived, or elusive group" for social scientists and she proposes to give a voice to children and to study children in their own right. By doing so, she offers a new scientific approach to children and contributes to the paradigm shift in the study of children. Departing from Hardman's observation of children as a silent group, James and Prout mention that, "the history of the study of childhood in the social sciences has been marked not by an absence of interest in children [...] but by their silence.” Thus they theorize the new paradigm made up of six articles (1997, p. 7):

"1. Childhood is understood as a social construction. As such it provides an interpretive frame for contextualizing the early years of human life. Childhood, as distinct from biological immaturity, is neither a natural nor universal feature of human groups but appears as a specific structural and cultural component of many societies.

2. Childhood is a variable of social analysis. It can never be entirely divorced from other variables such as class, gender, or ethnicity. Comparative and cross-cultural analysis reveals a variety of childhoods rather than a single and universal phenomenon.

3. Children's social relationships and cultures are worthy of study in their own right, independent of the perspective and concerns of adults.

4. Children are and must be seen as active in the construction and determination of their own social lives, the lives of those around them and of the societies in which they live. Children are not just the passive subjects of social structures and processes.

5. Ethnography is a particularly useful methodology for the study of childhood. It allows children a more direct voice and participation in the production of sociological data than is usually possible through experimental or survey styles of research. 
6. Childhood is a phenomenon in relation to which the double hermeneutic of the social sciences is acutely present (see Giddens, 1976). That is to say, to proclaim a new paradigm of childhood sociology is also to engage in and respond to the process of reconstructing childhood in society."

First of all, this point of view introduced by the new paradigm opens up the possibility for contextualizing children as well as their childhoods, therefore it prevents the children and their childhoods from the developmental gaze which considers a unique, universal and natural childhood based on biological age (Woodhead, 2009). In addition, this approach brings a plural view on children's experienced childhoods that are socially, historically and culturally situated and, constructed. Children are considered as members of a society who enters in relation with individuals, institutions and structures by contributing to their production and reproduction like any other adult members. As for childhood as a variable, it that cannot be separated from other variables such as class, ethnicity and gender. This second article, like the previous one, emphasizes the plurality of childhoods. Like all other social variables in sociological analyses, it is contextual and it contradicts the idea of a universal and unique concept of childhood. At the third point, inheriting from Charlotte Hardman's argument (2001 (1973), p. 502) about giving children a voice, James and Prout insist on the importance of studying children not from the point of view of the adults and their construction of the figure of the child, but on the contrary they propose to start from the experiences of the children, themselves. This approach moves the child from the position of an object to that of a subject in the research. Following that the consideration of children as active social actors brings the supposition that children are actively engaged in the social construction of their social lives and experiences; they are no longer seen as the passive receivers of social structures. This does not mean that children are outside the weight of social structures, on the contrary, as members of society they are subject to social constraints, but at the same time they contribute to their construction, deconstruction and reconstruction. With reference to the ethnography as a research method, the emphasis is placed on the importance of choosing the right method in the new sociology of childhood because of the direct interest in the first-hand experiences 
of children. This method is considered to be the one which permeates a better acquisition of the children's point of view. When it comes to the final article of the emergent paradigm, it is stated that engaging in research with and about children can contribute redefining childhoods as they are conceptualized by researchers. This can therefore have consequences on the perception of childhood at the level of society itself.

With the emergence of this paradigm for childhood studies, a new perspective is brought which mainly puts the child at the center of research and opens up new avenues of research methodologies and practices. According to the new paradigm, neither children can be marginalized nor excluded from the sociological research. At the center of this paradigm lays the fact that children are active social actors, they contribute to the changes around them and in the society in which they live.

\section{VARIED PERSPECTIVES, SAME ASSUMPTION : CHILDREN AS ACTORS}

Even if a new paradigm for the sociology of childhood is launched, this is not to say that there is only one way to do research with children or to conceptualize childhood. Departing from this paradigm, various approaches and perspectives are conveyed the sociology of childhood, children are treated in rather diverse ways. It is clear that the sociological concerns on childhood cannot be unified and singularized. Nevertheless, in spite of employment of different perspectives the one thing which is common to all these researches is the consideration that the children are social actors. As Children have increasingly become objects and subjects of social research children's cultures, children's peer cultures, childhood as a social structure, childhood as a minority group and socialization of children from a constructivist perspective have become the approaches most developed by researchers interested in researches with children. All these different perspectives approach children as they are active social actors by mobilizing different social theories and by adopting divers points of view.

$\mathrm{SAD} / \mathrm{JSR}$

Cilt / Volume 24 Sayı / Number 2
432 
Firstly, childhood cultures form one of the main areas of research in the sociology of childhood. This area is more specifically interested in the cultures and sociabilities that are created by children, themselves. Adults' point of view is excluded in this perspective, what matters is everything that happens among children in their own social worlds. Martine Court (2017, p. 49) describes these childhood cultures as "a place of production and learning of a culture of its own, made up of practices, beliefs and knowledge partially distinct from those transmitted by grown-ups." This approach to children's cultures considers children as social actors, and consists primarily on conducting ethnographic research with children in childish places where adults do not intervene. James, Jenks and Prout (1998, p. 28) call this consideration of children as "the tribal child." They point out that surveying children from such a point of view is like researching tribes with their own cultures. It is about taking children "seriously", in other words, the difference and the relative autonomy of children are being enhanced from this approach (Mayall, 1994). It is the social life of children between them that has its own functioning, its rules apart, and different from the world of adults. Children are considered as "producers of children's culture" (Brougère, 2006, p. 264). Researchers interested in children's cultures focus on practices like games, jokes, beliefs that are produced and shared in the moments of encounter between children on various occasions (Morin, 2010). These are practices that are transmitted orally from some children to others and take place in places of children's interaction which are generally far from the close supervision of adults (Arleo \& Delalande, 2011). Researches with regard to childhood cultures are conducted in school yards, during breaks, or in children's parks: jokes, nursery rhymes, secret languages, riddles and children's rituals are investigated (Opie \& Opie, 1969, 1977). In addition to these, children's traditions and practices are examined in terms of cultural transmission (Morin, 2010).

As for peer cultures, there is the idea of cultural transmission between peers. This process contributes to a new conceptualization of socialization which differs from its traditional functionalist use. Socialization in traditional terms is supposed to be vertical. A whole new approach to children's cultures opens the way to 
think about socialization differently, in this way the horizontal aspect is added to the socialization (Court, 2017). Starting from examination of children's birthdays, Régine Sirota (2006c, p. 57) emphasizes the socialization of the children and highlights how the children play a role in the process of their socialization considering the child as an actor in his own socialization, the child is both producer of the ritual and produced by it. Another point of view is brought by Julie Delalande (2006, p. 273), who adds another dimension to children's peer cultures. She underlines the contribution of adults in these cultures by saying that the concept of children's culture shows how children appropriate what adults teach them, transmit to them and set up for them. In a similar way, it is pointed out by researchers that in the social worlds of children, in their relationships with each other, there is a stratified structure, inequalities are negotiated and reproduced by children through their peer cultures (Adler \& Adler, 1998; Ambert, 1995; Thorne, 1993).

In the third place stands the perspective which considers the childhood as a social structure, thus a macrosociological approach is adopted. Working on social structures, Jens Qvortrup $(1993,1994,1997)$ provides a basis for taking into account childhood as a segment in social structures. He proposes that childhood must be understood as a permanent form of any generational structure (Qvortrup, 2009). In this approach, social structures are seen as social constructs and are therefore they are produced by members of a particular society according to various parameters. It is important to highlight that the permanence of these social structures are dependent on its members and that both children and adults play a constructive role (Qvortrup, 2005). As for Leena Alanen (2012), she places children in social structures and takes a very relational point of view, using the term 'generation' as the key to a new relational understanding of childhood. It is pointed out that she "detaches the concept of generation from its genealogical or life-course framework and abstracts it to a relation of power" (Honig, 2009). Children and adults are portrayed as asymmetric categories according to their power relationships. She introduces the concept of generationing as a process in which children have an active role (Alanen, 2001). By assigning an active role to any actor in the process, 
the difference between the actors, either adults or children, arises based on the power of the actors and their power relationships.

Another approach in the field of sociology of childhood considers children as members of a minority group. In fact, it is a political as well as a scientific stance on issues about children (Montandon, 2006). Researchers who focus on the power relations between adults and children position children in a network of hierarchical relationships. The studies from this perspective can be compared to feminist approaches, so that the place of women is considered similar to that of children (James et al., 1998). The major concern within this perspective is to question children as active, but dependent members in a discriminatory society. Ann Oakley (1994, p. 13) emphasizes that studies of women and children go hand in hand, emphasizing "the relationship between the status of women and children as social minority groups and their constitution as objects of the academic gaze." What makes this approach powerful is that it centralizes the interests and well-being of children, by centering upon children.

Another perspective in sociology of childhood is children's socialization. As William Corsaro (1997, p. 9) mentions that "for a model that truly incorporates an active child, we must consider the rise of constructivism", the sociological interest in children which is rendered possible by socialization theories has evolved over time. A constructivist point of view which considers children as active social actors has gradually taken place contrary to its traditional functionalist use. From the constructivist perspective, children's active participation and contribution to the process of their socialization is mentioned (Alanen, 1988). According to Gil Richard Musolf (1996), this process should be seen as an interaction between adults and children. Such a point of view that allows children to interact with adults renders children active and constitutive in that relationship. That is, children are given a role to play as actors (Honig, 2009). Norman Denzin (1977, p. 10), considering children as actors, indicates that "the child, like the adult, is able to shape, define, and negotiate its relationship to the external world of objects, others and social situations." 
Children are therefore treated by these researchers like all other social actors who play a central role in their own social world. There is a cooperative relationship between adults and children and it is within this cooperation the socialization takes place (Handel et al., 2007). According to this constructivist perspective, socialization is not a one way process (Waksler, 1991), it takes place in multiple and heterogeneous social contexts (Détrez \& Perronnet, 2020; Lahire, 1998), and children are actively and practically involved in this process (Lignier \& Pagis, 2017).

To summarize briefly, it is shown that researchers of sociology of childhood are interested in diverse issues concerning children. In order to examine these, they employ various perspectives, nonetheless they stay stick to the consideration that children are social actors.

\section{QUESTIONING CHILDREN'S AGENCY}

Another focal point of discussion takes place around the concept of agency. As mentioned earlier, researchers of children and childhood are "critical of dominant models that construct children as a facet of social structure, as passive with regard to the process of socialization but also as locked into a linear structure of development" (Oswell, 2020, p. 44). Contrary to these ideas childhood studies open up new avenues to think about children as social actors, as well as agents, such that it is managed through the concept of agency. While questioning the children as social actors, the concept of agency is put into the question and debated by researchers. In the context of Childhood Studies, children's agency is considered as children's active participation and the contribution in the production and reproduction of society (Oswell, 2020, p. 47), but the use of the term poses some problems.

Thus the major debate in childhood studies takes place around the dichotomy between structure and agency which are the concepts the most often discussed by researchers in this field. This is because the emergent paradigm of childhood studies introduces children as social actors in the first place. So the dichotomy is called into question in order to understand children's capacities to act in relation to their agency. Agency is 
above all understandable with its opposite which is the social structure. Social structure is one of the basic concepts of sociology. It considers the society as a sum of institutions comprising individuals, but also economy, education, legal system, religion and culture. The structural components of society play an important role in the social actions of groups and individuals; they become determining in several aspects. They restrict or allow the conduct and behavior of individuals.

The notion of agency is placed by researchers at the opposite of social structures. In this regard, with the new paradigm of Childhood Studies, children are no longer considered with regard to their lacks in relation to adults, but are attributed a certain autonomy. Agency is briefly described as "the capacity of individuals to act independently" by Allison James and Adrian James (2012, p. 4) in their book entitled Key Concept in Childhood Studies, and the children are considered as independent social actors with the capacity to make decisions concerning their own social worlds. That is to say that children are seen as other members of society who make "a difference to a relationship or to a decision, to the workings of a set of social assumptions or constraints" (Mayall, 2002, p. 21). This perspective bestows upon children an active role to play independently in a given society and "agency, in the end, is an attribute of individual children" (James, 2009, p. 44). As for Berry Mayall (2002), the children are considered as agents with an agency and mentioned as individuals having the capacity to interact with others and influence others in their entourage by emphasizing that an agent contributes to the processes of social and cultural reproduction.

However, in the field of sociology of childhood, the notion of agency refers to a position taking. According to Pascale Garnier (2015), it is a positioning where children are considered as social actors and childhood as social construction, and among the researchers who work with children there is no consensus on this concept. The contradiction arises from the simple description of the agency mentioned above which is "the capacity of individuals to act independently" (James \& James, 2012, p. 3). Contrary to this idea of independent action, Bernard Lahire (2019, p. 51) insists on the relationships of dependency between 
children and adults and he underlines that the weight of social structures is neglected while the concept of agency employed. He criticizes the agency as an attribute which would have no genesis and which would not be based on any determined social experiences. From this point of view, adults and children are not regarded separately, but they both are considered as actors. What is questioned is the "independent action" of actors enouncing that children are never passive, but they are particularly dependent on adults (Lahire, 2019, p. 53). In a similar way, Wilfried Lignier and Julie Pagis (2017, p. 11) stick to the idea of the "practical engagement" of children as actors and neglect the use of agency highlighting the dependence of child actors. As for Martine Court (2019, p. 42), the concept is criticized because it is considered as essentialist and of extra-social nature. The critics are based on the fact that the concept of agency is employed in a rather deterministic way.

These researchers criticize the use of agency as a taken for granted attribute to child actors by positioning themselves in opposition to Childhood Studies, while some others do the same by still positioning in this field, but discussing the essentialist aspect of the concept and proposing new understandings of it. Encountering the same obstacle, the concept of agency has become the subject of debates under the pen of several researchers. Spyros Spyrou (2018, pp. 121-122), the co-editor of the international journal Childhood, puts it into discussion precisely as "Despite its productive trajectory, the 'discovery' of the independent and autonomous child-agent has become in many ways a conceptual trap for childhood studies and an obstacle to its theoretical imagination. It could be argued that this reductionist view of children's agency—agency as self-possession—has resulted in a theoretical dead-end for the field." He questions how to advance in studies on children and childhood by adopting a critical point of view in the use of this concept fundamental to the field and proposes the use of this term by rethinking the agency relationally. It means that agency is a result of social relations rather than an essential quality attributed to the children. It is stressed that considering agency as a relational concept permeates 
highlighting the interdependency between children and adults, furthermore it underlines their willingness for negotiating the space of agency (Spyrou, 2018, p. 128).

One of the descriptions which addresses the relational character of this concept is proposed by Michael Wyness (2015, p. 13) mentioned "as a relational concept, an effect of complex shifting social arrangements" highlighting the relations of interdependence in which children are integrated. Such that there is an emerging trend that considers the agency as a relational, dispositional and context dependent concept. It is neither something to be possessed a priori, nor it exists essentially in individuals. It means that it is not taken for granted. As Alan Prout (2000, p. 17) points out, the agency is produced through empirically discursive, biological, technological resources and by their the connections. From the same perspective, the heuristic value of the concept of agency is highlighted and it is thought "as a resource and an evolving process 'distributed and shared by children and adults'(Garnier, 2015, p. 168)" by avoiding its use as an essential attribute of the children (Détrez \& Perronnet, 2020, p. 105).

As a contested concept, agency is widely discussed by childhood researchers. Although it is considered to be directly linked to the assumption that children are social actors, there have been diverse uses of this term. 


\section{CONLUSION}

To summarize, this article investigated the child actors in the sociology of childhood focusing on diverse research perspectives and different employments of the concept agency. In particular, I explored how this field of sociology approached the children as actors and it is reflected in the studies of researchers.

In the first place, it was shown the importance of the theories of socialization from the functionalist perspective. It is because these theories are the first ones in sociology to bring the sociological gaze at children. They make the children the objects of the sociological inquiry. By doing so, they consider them as passive entities to be shaped by society. Although this is found to be problematic and objected to debates, the functionalist perspective of socialization opens new avenues of investigation about children. Once the children become the objects of social research, then the place of children has started to be discussed. These discussions manifest themselves with the emergence of the new paradigm for childhood studies.

When it comes to the new paradigm, children are approached from a totally different perspective. They are considered as active social actors who contribute to changes in their entourage, making a difference in their own social worlds. They become the subjects of social research, their point of view is no more neglected in favor of adults. Children are investigated in their own right. As the forgotten and neglected categories of the social research who form the one third of the total population worldwide, it is during the last four decades that children are given a voice. After the emergence of this paradigm which centers upon children, social sciences witness production of numerous studies on children and their childhoods with regard to children's own experiences.

The common assumption that the children are social actors is manifested itself in different ways among the researchers: the research perspectives and the core concept that is agency.

While considering children as active actors in their studies, researchers carry their work from different perspectives. The first group highlights the childhood cultures focusing on children's own activities. This 
is what children culturally produce while they are with other children including games, jokes, beliefs, practices. From this point of view, children are the only social actors because these are children's spaces where adults don't have any place. The second group is directly linked to the first one. It is children's peer cultures which focus on relationship and the transmission between peers. This point of view brings another dimension to the theories of socialization because of the fact that it considers socialization as horizontal, not vertical. It holds the idea that children are socialized to be children in the first place, before socializing to be future adults of the society. This process of horizontal socialization occurs between peers during the moments of exchange on diverse occasions. When it comes to the perspective which approaches childhood as a social structure, it is considered that actors contribute to the production, reproduction and the destruction of social structures. While mentioning actors, children are not excluded. They are attributed an important role as active social actors. From this point of view, the difference between the roles of adults and children and their capacities to act rests on the idea that the asymmetric power relations between these two categories may result different contributions of the former and the latter. As for researchers who hold the idea of children as a minority group, they mention that feminist studies and childhood studies go hand in hand. Because both of them investigates the mostly muted categories of society. This perspective considers, like others, children as social actors and gives them a voice to be heard in a discriminatory society. In the last place come the theories of socialization from the constructivist perspective which hold the same assumption about children. Challenging the functionalist perspectives of socialization, they pinpoint that socialization is not a process through which children rest passive, but they actively contribute to their own socializations. The relationships between adults and children are not that of imposition but cooperation. Therefore children are actively involved in their socialization process during childhood and their lifetime. These different approaches on children and their childhoods show that even though researchers hold various perspectives, the assumption that children as social actors rests the key point of their researches. 
When it comes to the concept of agency, it was mentioned in the article that despite this concept has its sources from the idea that children are social actors, researchers consider it in different manners. First of all, it is described as individuals' independent capacities of acting and placed on the contrary of social structures. From that point emerges three different ideas on children's agency in relation to children's capacities of acting. The first one considers agency as an attribute, from that point of view the agency is viewed as an a priori possession of children. The idea that children have agency is taken for granted without any discussions on it. It is considered that children, with regard to their agency, contribute to their social worlds. The problem with this point of view is that it is found to be deterministic and essentialist. It is at this point that the ideas of a second group of researchers emerge. This group neglects the use of the concept agency, while still considering children as social actors and mentioning that children actively engage in their social lives and in their socializations. They question the concept of agency mentioning that it has no genesis based on social experiences of individuals. It is underlined that attributing children agency neglects the weight of social structures. Therefore the use of agency is denied in the studies with children from this point of view. Lastly, by opposing to these two approaches, emerges the idea that agency is a relational concept. Like the second perspective, agency as a self-possession is objected. Agency is proposed to be a relational concept, depending on contexts and relationships. The interdependency of social actors is underlined and the agency is regarded to be produced, distributed and shared between actors in diverse contexts. These three uses of agency from different perspectives show that it is a disputable concept despite it is directly linked to the consideration that children are social actors.

In conclusion, this article has focused on children from the perspective of sociology of childhood and it has contributed to the theoretical investigations of children and childhood carried out by researchers in Turkey. It has principally aimed at fulfilling the lack of theoretical works focusing on and discussing the major consideration of sociology of childhood which is that the children are social actors. In the end, it is purposed that this article opens up new debates on children and new avenues for investigating their childhoods.

$\mathrm{SAD} / \mathrm{JSR}$

Cilt / Volume 24 Say1 / Number 2

$$
442
$$




\section{ÖZET}

Bu makale, çocukluk sosyolojisinin temel varsayımına odaklanmıştır, buna göre çocuklar toplumsal birer aktördür.

Çocuklar ilk olarak işlevselci yaklaşımın sosyalizasyon teorileri ile sosyal bilimlere konu olmuşlardır. Bu yaklaşım çocukları pasif olarak etmiş toplumun çocukları şekillendirdiğini öne sürmüştür. 1980'li y1llarda bu yaklaşıma bir tepki olarak, çocukluk çalışmaları yeni bir paradigmayla ortaya çıkmışlardır. Yeni paradigmanın temel kabulü çocukların aktif birer toplumsal aktör olduğudur. $\mathrm{Bu}$ kabul, çocukluk çalışmaları ve çocukluk sosyolojisinin önünü açmıştır ve çocukları merkeze alan pek çok çalışma gerçekleştirilmiştir.

Gerçekleştirilen araştırmalarda temel kabul çocukların aktif birer toplumsal aktör olmalarından yola çıksa da, araştırma perspektifleri ve de faillik kavramını ele alma şekillerinin birbirlerinden farklılaşmalarına sebep olmuştur.

Araştırma perspektiflerini ele alacak olursak, burada çeşitli yaklaşımlar dikkat çekmektedir. Bunlar sırasıyla çocuk kültürü, akran kültürü, bir sosyal yapı olarak çocukluk, toplumsal bir azınlık olarak çocukluk ve sosyalize olan çocuklara toplumsal inşacı yaklaşımdır. Tüm bu yaklaşımlar aracılığıyla araştırmacılar çocuklarla ilgili ve çocuklarla birlikte araştırmalar gerçekleştirmişlerdir. Çocuklar araştırmanın merkezini oluşturmuş, tamamında çocukların aktif katılımı ve katkısı ele alınmıştır.

Faillik kavramına gelecek olursak, altı çizilmelidir ki bu kavram, çocukların toplumsal aktör olmalarıla ilişkilendirilmiştir. Çocukların aktör olarak kabulü, faillik kavramını da tartışmaya açmıştır. Bu tartışmalar arasında üç farklı yaklaşım göze çarpmaktadır. Birincisi failliğin, çocukların bir niteliği olduğunu var sayar; buna göre çocuklar tartışmasız bir şekilde kendiliklerinden birer faildirler. İkinci yaklaşım, birinciyi indirgemeci olmakla eleştirir ve bu kavramı kullanmayı reddeder, ancak yine de çocuklar aktör olarak kabul görmektedir. Üçüncü yaklaşım ise kendini bu iki yaklaşım dışında konumlandırır ve faillik kavramına 
ilişkisel bir boyut katar ve onu indirgemeci yaklaşımdan uzaklaştırır. Dolayısıyla çocukluk sosyolojisinde faillik kavramı çocukların toplumsal aktör olmaları üzerinden tartışmaya açılsa da, kavram farklı şekillerde tartışılmış ve kullanılmıştır.

Çocukluk sosyolojisinde çocukların toplumsal aktörler olarak kabulünü araştırma perspektifleri ve faillik kavramı aracılığıyla tartışmaya açmasıyla, bu makale Türkiye'deki çocukluk sosyolojisi yazınına katkı sağlamaktadır. Bu tartışmayla birlikte, çocukluk sosyolojisi alanında yeni kavramsal tartışmalar yapılması ve araştırmalar gerçekleştirilmesi için bir çıkış noktası olmayı amaçlamaktadır. 


\section{REFERENCES}

Adler, P. A., \& Adler, P. (1998). Peer Power: Preadolescent Culture and Identity. Rutgers University Press.

Akbaş, E., \& Akbaş, G. E. (2019). Çocukluk Sosyolojisinin Özgün Sahası: Çocuklarla Nitel Araştırma. Çocuk ve Medeniyet, 4(7), 149-162.

Alanen, L. (1988). Rethinking Childhood. Acta Sociologica, 31(1), 53-67. https://doi.org/10.1177/000169938803100105.

Alanen, L. (2001). Explorations in Generational Analysis. In B. Mayall \& L. Alanen (Eds.), Conceptualising Child-Adult Relations (pp. 11-22). Routledge.

Alanen, L. (2012). Moving Towards A Relational Sociology of Childhood. In R. Braches-Chyrek, C. Röhner, \& H. Sünker (Eds.), Kindheiten. Gesellschaften: Interdisziplinäre Zugänge zur Kindheitsforschung (1st ed., pp. 21-44). Verlag Barbara Budrich.

Ambert, A.-M. (1995). Sociological Studies of Children. Emerald Group Publishing Limited.

Arleo, A., \& Delalande, J. (Eds.). (2011). Cultures Enfantines. Presses Universitaires de Rennes.

Aydoğmuş Ördem, O. (2020). Türkiye'de Çocukluk Sosyolojisi. OPUS Uluslararası Toplum Araştırmaları Dergisi, 16(31), 4469-4492. https://doi.org/10.26466/opus.727041.

Brougère, G. (2006). Le jouet, un objet pour la sociologie de l'enfance? In R. Sirota (Ed.), Éléments pour une sociologie de l'enfance (pp. 257-266). Presses Universitaires de Rennes.

Corsaro, W. A. (1997). The Sociology of Childhood. SAGE Publications.

Court, M. (2017). Sociologie des Enfants. La découverte.

Court, M. (2019). Socialisations Primaires. Constructions du genre et différenciations de classe au cours de l'enfance [Mémoire de synthèse en vue de l'obtention de l'Habilitation à Diriger des Recherches]. l’École des Hautes Études en Sciences Sociales.

Danziger, K. (Ed.). (1970). Readings in Child Socialization. Pergamon Press.

Darmon, M. (2010). La Socialisation: Domaines et Approches (2. édition). Armand Colin.

$\mathrm{SAD} / \mathrm{JSR}$

Cilt / Volume 24 Sayı / Number 2 
Delalande, J. (2006). Le concept heuristique de culture enfantine. In R. Sirota (Ed.), Éléments pour une sociologie de l'enfance (pp. 267-274). Presses Universitaires de Rennes.

Demir Gürdal, A. (2013). Sosyolojinin İhmal Edilen Kategorisi Çocuklar Üzerinden Çocukluk Sosyolojisine ve Sosyolojiye Bakmak. 'İş, Güç' Endüstri İlişkileri ve İnsan Kaynakları Dergisi, 15(4), 1-26. https://doi.org/DOI: 10.4026/1303-2860.2013.0234.x.

Denzin, N. K. (1977). Childhood Socialization. Transaction Publishers.

Détrez, C., \& Perronnet, C. (2020). New Avenues to Investigate Childhood from the Perspective of the Sociology of Culture: A Conversation between Christine Détrez and Clémence Perronnet. Youth and Globalization, 2(1), 101-110.

Elkin, F., \& Handel, G. (1972). The Child and Society: The Process of Socialization. Random House.

Firınc1 Orman, T. (2018). Observing the Late Development of Childhood Sociology in Turkey. In The Modernizing Process in Turkey (pp. 199-214). Nomos Verlagsgesellschaft mbH \& Co. KG.

Garnier, P. (2015). L"“agency" des enfants. Projet scientifique et politique des "childhood studies". Education et sociétés, 2(36), 159-173. https://doi.org/DOI: 10.3917/es.036.0159.

Goslin, D. A. (1969). Handbook of Socialization Theory and Research. Rand McNally.

Güçlü, S. (2016). Çocukluk ve Çocukluğun Sosyolojisi Bağlamında Çocuk Hakları. Ege Üniversitesi.

Handel, G., Cahill, S., \& Elkin, F. (2007). Children and Society: The Sociology of Children and Childhood Socialization. Roxbury Pub.

Hardman, C. (2001). Can there be an Anthropology of Children? Childhood, 8(4), 501-517.

Honig, M.-S. (2009). How is the Child Constituted in Childhood Studies? In J. Qvortrup, W. Corsaro, \& M. Honig (Eds.), The Palgrave Handbook of Childhood Studies (pp. 62-76). Palgrave Macmillan UK.

Işık, E. (2019). Batı'da Çocukluk Sosyolojisi Çalışmaları Tarihi. Çocuk ve Medeniyet, 4(7), 179-194.

James, A. (2009). Agency. In J. Qvortrup, W. Corsaro, \& M. Honig (Eds.), The Palgrave Handbook of Childhood Studies. Palgrave Macmillan UK.

$\mathrm{SAD} / \mathrm{JSR}$

Cilt / Volume 24 Sayı / Number 2 
James, A., \& James, A. L. (2012). Key Concepts in Childhood Studies. SAGE.

James, A., Jenks, C., \& Prout, A. (1998). Theorizing Childhood. Polity Press.

James, A., \& Prout, A. (1997). A New Paradigm for the Sociology of Childhood? Provenance, Promise and Problems. In A. Prout \& A. James (Eds.), Constructing and Reconstructing Childhood: Contemporary Issues in the Sociological Study of Childhood (2., pp. 7-32). Falmer Press.

Jenks, C. (1982). The Sociology of Childhood: Essential Readings. Batsford Academic and Educational.

Karabıyık, M. S. (2019). Yeni Sosyolojilere Doğru İmkân ve Fırsatlar: Bir Disiplin Olarak Çocukluk Sosyolojisi. Çocuk ve Medeniyet, 4(7), 163-178.

Lahire, B. (1998). L'homme pluriel: Les ressorts de l'action. Nathan.

Lahire, B. (2019). Enfances de classe. Seuil.

Lignier, W., \& Pagis, J. (2017). L'enfance de l'ordre. Seuil.

Mayall, B. (1994). Children's Childhoods: Observed and Experienced (B. Mayall, Ed.). The Falmer Press.

Mayall, B. (2002). Towards a Sociology for Childhood: Thinking from Children's Lives. Open University Press.

Mayall, B. (2013). A History of the Sociology of Childhood. Institute of Education Press.

Montandon, C. (2006). De l'étude de socialisaiton des enfants à la sociologie de l'enfance: Nécessité ou illusion épistémologique? In R. Sirota (Ed.), Éléments pour une sociologie de l'enfance (pp. 4150). Presses universitaires de Rennes.

Morin, O. (2010). Pourquoi les enfants ont-ils des traditions? Terrain. Anthropologie \& sciences humaines, 55, 20-39. https://doi.org/10.4000/terrain. 14042

Musolf, G. R. (1996). Interactionism and the Child: Cahill, Corsaro, and Denzin on Childhood Socialization. Symbolic Interaction, 19(4), 303-321. https://doi.org/10.1525/si.1996.19.4.303

Oakley, A. (1994). Women and Children First and Last: Parallels and Differences between Children's and Women's Studies. In B. Mayall (Ed.), Children's Childhoods: Observed and Experienced. The Falmer Press.

$\mathrm{SAD} / \mathrm{JSR}$

Cilt / Volume 24 Sayı / Number 2 
Onur, B. (2007). Çocuk, Tarih, Toplum. İmge Kitabevi Yayınları.

Opie, I., \& Opie, P. (1969). Children's Games in Street and Playground. Oxford University Press.

Opie, I., \& Opie, P. (1977). The Lore and Language of Schoolchildren. Oxford University Press.

Oswell, D. (2020). Agency. In D. T. Cook (Ed.), The SAGE Encyclopedia of Children and Childhood Studies (Vol. 1, pp. 1473-1474). SAGE Publications.

Parsons, T. (1951). The Social System. Routledge \& Kegan Paul.

Piaget, J. (1952). The Origins of Intelligence in Children. International Universities Press.

Piaget, J. (1967). Six Psychological Studies. Random House.

Prout, A. (Ed.). (2000). The Body, Childhood and Society. Macmillan [u.a.].

Prout, A. (Ed.). (2005). The Future of Childhood. Routledge.

Qvortrup, Jens. (1993). Nine Theses about “Childhood as a Social Phenomenon”. na.

Qvortrup, Jens. (1994). Childhood Matters: An Introduction. In Jens Qvortrup (Ed.), Childhood Matters: Social Theory, Practice and Politics. Avebury.

Qvortrup, Jens. (1997). A Voice for Children in Statistical and Social Accounting: A Plea for Children's Right to be Heard. In A. James \& A. Prout (Eds.), Constructing and Reconstructing Childhood (2.). Falmer Press.

Qvortrup, Jens. (2005). Varieties of Childhood. In Jens Qvortrup (Ed.), Studies in Modern Childhood. Society, Agency, Culture. Palgrave Macmillan UK.

Qvortrup, Jens. (2009). Childhood as a Structural Form. In J. Qvortrup, W. Corsaro, \& M. Honig (Eds.), The Palgrave Handbook of Childhood Studies (pp. 21-33). Palgrave Macmillan UK.

Sirota, R. (Ed.). (2006a). Éléments pour une sociologie de l'enfance. Presses universitaires de Rennes.

Sirota, R. (2006b). Petit objet insolite ou champ constitué, la sociologie de l'enfance est-elle encore dans les choux? In R. Sirota (Ed.), Éléments pour une sociologie de l'enfance. Presses universitaires de Rennes. 
Sirota, R. (2006c). Prendre au sérieux un rite de l'enfance: L'anniversaire. In R. Sirota (Ed.), Éléments pour une sociologie de l'enfance (pp. 51-59). Presses universitaires de Rennes.

Spyrou, S. (2018). Disclosing Childhoods. Palgrave Macmillan UK.

Stainton-Rogers, W., Hevey, D., \& Ash, E. (Eds.). (1989). Child Abuse and Neglect: Facing the Challenge (2ème édition). Batsford Ltd.

State of the World's Children 2019: Statistical tables and interactive dashboard. (2019, October 18). UNICEF DATA. https://data.unicef.org/resources/sowc-2019-statistical-tables-and-interactivedashboard/

Thorne, B. (1993). Gender Play: Girls and Boys in School. Open University Press.

Turmel, A. (2006). De la Fatalité de Penser la Maturation en Termes de Développement: Quelques Réflexions. In R. Sirota (Ed.), Éléments pour une sociologie de l'enfance (pp. 63-72). Presses universitaires de Rennes.

Convention on the Rights of the Child, (1989). https://www.unicef.org.uk/wpcontent/uploads/2016/08/unicef-convention-rights-child-uncrc.pdf

Vygotsky, L. S. (1978). Mind in Society. Harvard University Press.

Waksler, F. C. (1991). Studying the Social Worlds of Children: Sociological Readings. Falmer Press.

Woodhead, M. (2009). Child Development and the Development of Childhood. In J. Qvortrup, W. Corsaro, \& M. Honig (Eds.), The Palgrave Handbook of Childhood Studies (pp. 46-61). Palgrave Macmillan UK.

Wyness, M. (2015). Childhood. John Wiley \& Sons. 